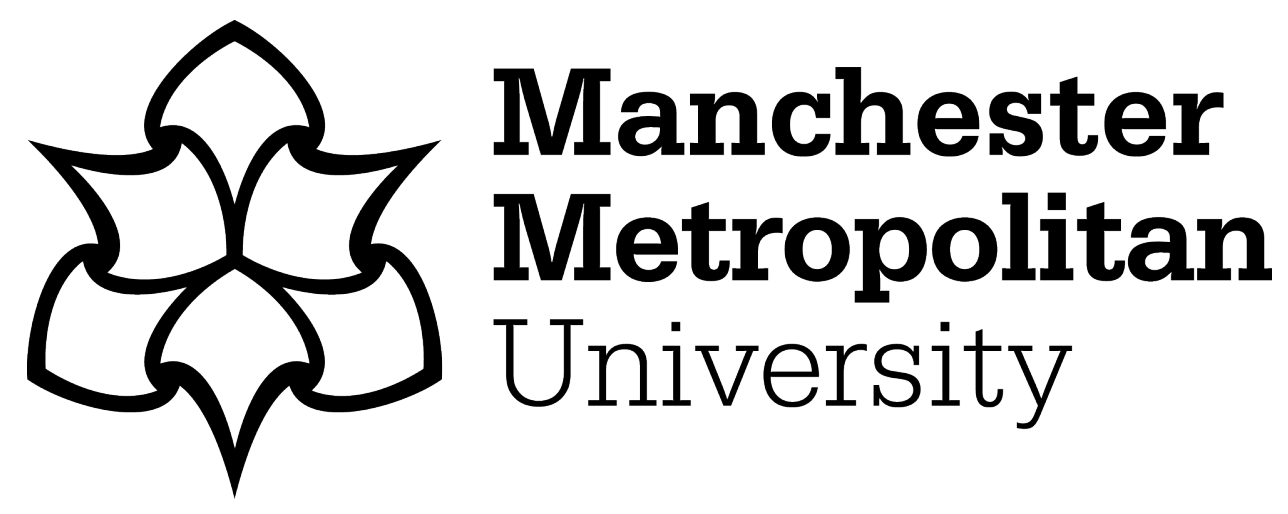

Archer, D ORCID logoORCID: https://orcid.org/0000-0002-4547-6518 (2015) Slurs, insults, (backhanded) compliments and other strategic facework moves. Language Sciences, 52. pp. 82-97. ISSN 0388-0001

Downloaded from: https://e-space.mmu.ac.uk/627203/

Version: Accepted Version

Publisher: Elsevier

DOI: https://doi.org/10.1016/j.langsci.2015.03.008

Usage rights: Creative Commons: Attribution-Noncommercial-No Derivative Works 3.0

Please cite the published version 


\title{
Slurs, insults, (backhanded) compliments and other strategic facework moves
}

\author{
Dawn Archer
}

University of Central Lancashire, UK

\begin{abstract}
Slurs such as nigger tend to function as "disparaging remarks": that is, they are an attempt by speakers (S) to deliberately deprecate a target - or targets (T) - in some way (Croom, 2011). Accordingly, they can be seen to share the same pragmatic space as other verbally aggressive acts such as insults, put-downs, snubs and backhanded compliments (Jucker and Taavitsainen, 2000). Mention of backhanded compliments, in turn, serves as a useful reminder that compliments can be seen as representing the positive end of a larger pragmatic space relating to the speaker's evaluation of the addressee, with slurs and insults representing the negative end (Taavitsainen and Jucker, 2008) and back-handed compliments, a positive/negative blend. In this paper, I introduce a facework scale that serves to capture face-enhancing and face-threatening strategies (and combinations thereof). It can thus explain various uses of terms such as nigger: for example, its use in order to slur or negatively frame another (Croom, 2011); its use (by in-group members) to express affection for or approval of another (Smitherman, 2006); and unsuccessful cases of (re-)appropriation (Bianchi, 2014) such that an utterance meant to build camaraderie between $S$ and $T$ ultimately serves to offend T. The facework scale can also explain additional facework moves, such as S's use of strategic facework strategies which afford them some plausibility deniability (Archer, 2011; Leech, 1983). Although paradigmatic slurs are not likely to be (strategically) denied by S, given their overt use in insulting, injuring, threatening the face of, or otherwise imposing a negative identity on T (Croom, 2013: 178), facework which is strategically ambivalent in some way(s) can be an effective means of $S$ manipulating others' views of T without explicitly "doing" impoliteness (Archer, 2011). This work thus contributes to the field of im/politeness research as well as to the growing body of (pragmatic) research focussing on slurs.
\end{abstract}

\section{Introduction}

In line with the overall aim of this particular volume of work, one of my objectives in this paper is to take a substantive step forward in capturing the facework involved in (strategically) slurring, insulting, injuring, threatening the face of, or otherwise imposing a negative identity on a given target $(\mathrm{T})$. Consider slurring for example. The uttering of nigger, faggot and slut in order to slur constitutes an overt strategic denigration of T (Croom, 2011). Indeed, like abusive swearwords (fucker, shit) and other more general pejoratives, nigger, faggot and slut offer speakers (S) 'a uniquely expressive resource with which to convey their subjective feelings, perspectives and emotions' about T (Croom, 2013: 178). Unlike swearwords, however, slurs constitute more than just 
an emotional outburst on S's part. This is because the paradigmatic aim of slurs is to associate T negatively with an ethnically-/gender-loaded descriptive feature $X$ - where $X$ (from S's perspective) might be T's inferior ethnicity, decadent sexual orientation, excessive sexual activity, etc. It is this directed focus that also makes slurs different to more general pejoratives like loser and idiot, of course (Croom, 2014: 232-236); especially in respect to restricting the potential for S to claim plausible deniability (Leech, 1983) should they wish to deny the implicature of their utterances. It is possible to use some slurs derogatively but non-paradigmatically, nonetheless. Faggot tends to be regarded as a sexist slur (associated with homosexuality), but can also be used in certain contexts to signal other negative attributes (Croom, 2013: 190): for example, that, from S's perspective, $T$ is an "idiot", "loser", etc. It is possible, in addition, for in-group members to use terms such as faggot and nigger non-derogatively. Bianchi (2014) provides the example of two gay friends talking about a new colleague, and one uttering: I'm sure Tom is a faggot (2014: 40). Important points made by Bianchi, in this case, include that $\mathrm{S}$ was committing himself to the belief that Tom is homosexual, but not to the offensive content expressed or conveyed by faggot when used as a slur by members of the "dominant community". The gay friends were also speaking privately. Similarly, Croom (2013: 19094) highlights a plethora of studies where nigger has been appropriated by certain groups such that its in-group meaning(s) signify a level of social intimacy (Brown and Levinson, 1987), banter (Leech, 1983; Culpeper, 1996), teasing (Drew, 1987) or even what Croom (2013) has labelled verbal roughhousing. What all of these studies emphasise, however, is that having the right in-group status is crucial if terms such as nigger are going to be heard/understood non-offensively. This is evident in Smitherman's (2006: 58) other-focussed claim that many 'from the Old Skool [sic] have heard or use nigga [sic] in everyday conversations with other Blacks' (my emphasis) as well as in Clinton Brown's self-focussed claim below (cited in Smitherman, 2006: 58): 
I have heard the word niggah (note the spelling, dig the sound) all of my life. Many of my elders and friends use it with phenomenal eloquence. They say it to express amusement, incredulity, disgust or affection. These people are very much about being themselves proudly, intensely, sometimes loudly (my emphasis).

(1) is thus very different to (2), involving Emily Parr. Emily (a white woman) was taking part in Series 8 of the British version of the Big Brother reality TV show. During a conversation with two female participants, with whom she appeared to be on very friendly terms, Emily referred to Charley Uchea (a black woman) using the term, nigger:

(2) Big Brother, Series 8, 6th June 2007

1 Charlie: I hope I'm not pregnant I-

Emily: ohh, you're pushing it aren't you nigger

Z:

[audible intake of breath heard, accompanied by sounds and gestures depicting surprise/shock]

2 Charlie: [leaning close to Emily] [you're in trouble Emily: I'm so- don't don't make a meal out of it

Z: $\quad$-Emily, I can't believe you [said that

3 Charlie: you're in trouble I know you were but you are in some Emily: though I was joking

Z:

$4 \quad$ Charlie: serious shit sorry. oh my god I'm not even saying anything

Emily: why? I was joking

Z:

5 Charlie: $\quad$-SHUSH [oh my god. do you know how many

Emily: $\quad$ I was jok[ing

Z: no. just don't talk about it-

6 Charlie: viewers are watching out there there's [probably going to be [xxx] big [xxx] Emily:

Z: [don't make a big deal out of it

7 Charlie: fancy you saying that [xxxxx] no way

Emily: $\quad$ someone's already used that word in this house

Z:

8 Emily:

Charlie: near me? I'm a nigger I am one. oh. fancy using it in here. maybe Z:

9 Emily:

[suppressed laugh]

Charlie: you see it in rap songs or something

$[x x x x x x x x x x x x x x x x]$

Z:

10 Emily: yeah. they call me niggers. they do.

Charlie:

they're saying it 
11 Emily: they call me wizard as well

Charlie: you. I'm fucking in shock Emily

12 Charlie:

Emily: it's not a big deal though is it?

Z:

Note how Emily claimed to have not used the term offensively in (2) above. On the contrary, she appeared to suggest that nigger was a non-derogatory in-group term amongst her friends (i.e., similar to (1)), and thus her use of it was not a big deal. But it was a big deal. Indeed, Emily's use of nigger in this context shocked those present with her (see Section 4.6), notwithstanding their acceptance that her actions seemed to constitute a failed attempt at building social cohesion (cf. Section 4.1) as opposed to being a deliberate attempt to offend them (cf. Section 4.2). The general public also found it to be a big deal (contra Emily's assertion): the show received a wealth of protests, and Emily was removed from the Big Brother house. Possible conclusions we might glean at this point? First, that Emily misjudged a public context to be a private one (compare the two gay friend's use of faggot reported in Bianchi, 2014). Second, the use of nigger by 'a white kid' was not explicitly legitimated 'by a way of dressing, walking and talking', etc., that indisputably linked Emily to, say, the hip hop culture (cf. Bianchi, 2014: 43; Croom, 2013: 191).

Particular context specific and in-group uses apart, then, slur terms tend to be amongst those 'words and phrases' which have inherent, offensive meanings for many 'non-technical, non-academic, or 'lay users" (Bousfield, 2010: 109). Hence Croom's (2013: 183) use-conditions for slurring terms:

As speakers we have strong expectations that uses of slurring terms such as nigger will correlate with the speaker[s]'s being in a heightened derogatory state with respect to some features of their target (or wishing to create that impression). In turn, we use it only when we are in such a state (or wish to create that impression). The total effect of these assumptions is that a slurring term such as nigger is a prima facie reliable signal of derogation on the basis of target features. Knowing its use conditions largely involves being attuned to this information. 
Indeed, nigger, faggot, etc., can be used as slurs even within the in-groups that have fought so hard to subvert or reappropriate their prima facie offensive meanings (Bianchi, 2014: 43). In Sections 44.7, I will introduce a scale I have devised to account for a variety of facework strategies. It is advanced, here, on two inter-related premises. First, that face enhancement devices such as compliments represent the positive end of a pragmatic space relating to S's evaluation of the addressee, and face aggravating devices like insults and slurs, the negative end (Taavitsainen and Jucker, 2008). Second, that this shared evaluative space helps to explain why compliments can function as insults in context, due to their insincerity (Archer, 2010), and insults, slurs, etc., can be intended/inferred as banter in context (Culpeper, 2005: 43). As will become clear from Sections 44.7, the facework scale can thus account for:

(i) Strategic uses of a term such as nigger to achieve face aggravation or face enhancement.

(ii) The (strategic) use of additional face-enhancing and face-aggravation strategies not reliant upon slur terms, including banter, (backhanded) compliments, impoliteness, etc.

(iii) Those occasions where $\mathrm{S}$ signals a level of strategic ambivalence, on their part, in respect to their exact facework intention.

(iv) Those occasions (like (2)) when what might be intended by $\mathrm{S}$, in facework terms, is not always understood in the same way by T and/or others.

To explain the various zones within the facework scale, I will pick up again on extracts (1) and (2) above, draw on new data taken from the 2014 TV series Britain's Got Talent, and also make use of facework examples from other studies (Leech, 1977; Jane and Buckley, 1999; Cotterill, 2003; Eckert and McConnell-Ginet, 2003; Magnussan, 2004; Culpeper, 2005, 2011; Graham Scott, 2006; Archer, 2008, 2010, 2014; Bousfield, 2008; Cheung and Pittam, 2012; Huang, 2012). As these extracts denote different periods in time, as well as different activity types, they should point to the versatility of the 
facework scale. ${ }^{1}$ This work, in addition, builds on and extends the face aggravation scale (FAS) I have previously devised (and discuss at length in Archer, 2011): especially in respect to S's use of FTAs which are strategically ambivalent in facework terms (and the possible reasons for so doing). Given my specific focus on "slurs, insults, (backhanded) compliments and other facework moves", in this paper, I will begin by describing the pragmatic space of verbal aggression (Section 2), and outline FAS (Section 3), before moving on to describe the new zones of the facework scale.

\section{The pragmatic space of verbal aggression}

In their insults paper, Jucker and Taavitsainen (2000) provide an account of deliberately offensive speech acts across fourteen centuries, ending with a discussion of flaming (the term used to denote hostile/insulting interaction between internet users). Rather than applying speech act theory in a Searlean sense, however, they advocate a prototype approach. For example, insults are described as sharing a multidimensional pragmatic space with slander, slurs, swearing and related face threatening acts (FTAs), owing to their disparaging predication about the target. This disparagement, moreover, can be signalled on a number of levels (according to insult type). Thus:

$\begin{array}{lll}\text { Formal level } & \begin{array}{l}\text { Ritual, rule governed } \\ \text { Typified }\end{array} & \begin{array}{l}\text { Creative } \\ \text { Adhoc }\end{array} \\ \text { Semantics } & \text { Truth conditional } & \text { Performative } \\ \text { Context dependence } & \text { Conventional } & \text { Particular } \\ \text { Speaker attitude } & \begin{array}{l}\text { Ludic } \\ \text { Intentional } \\ \text { Irony }\end{array} & \begin{array}{l}\text { Aggressive } \\ \text { Unintentional }\end{array} \\ & \text { Reaction in kind } & \text { Sincerity } \\ \text { Reaction } & \text { Denial, violence, silence }\end{array}$

Fig. 1. Pragmatic space of insults (adapted from Jucker and Taavitsainen, 2000: 74).

\footnotetext{
${ }^{1}$ The present materials are not sufficiently robust to allow for a discussion of the diachronic development of particular facework strategies (including slurs). But this is something I hope to research in the future.
} 
I mention Jucker and Taavitsainen's approach so that I might point out how it overlaps to some extent with my own approach to verbal aggression (see Archer, 2008, 2011; and also Section 3). I prioritise the speaker's facework intention - including the level of verbal aggression they display (cf. the speaker attitude cline in Fig. 1) - but in a given context-of-use. Within a courtroom context, for example, the role of a cross-examining lawyer in particular requires, indeed, licences them to systematically aggravate the face of unfriendly witnesses (Culpeper, 1998: 86, 359) via sequences of face-threatening (an, in some instances, face-damaging) cross-examination questions. Their primary aim in using such verbally aggressive strategies is not to communicate a sense of personal spite or malice, however, for legal constraints prohibit lawyers from acting in such ways (cf. Goffman's, 1967: 14 intentional face threat level). Rather, a cross-examining lawyer will use verbally aggressive strategies with the primary aim of developing a convincing crime narrative or counter-narrative (within the Anglo-American adversarial system, at least). In the context of a call centre, in contrast, it is the callers as opposed to the agents who tend to engage in face threatening - and, in some instances, face-damaging - acts (Jagodzinski, 2013). On occasion, it is obvious the callers are meaning to "do" impoliteness in such cases. That is to say, they make clear that they are deliberately aggravating the professional face of the call-centre agent (as representative of that company); and that this face-damaging intention outweighs any other possible intention(s) they may have (Culpeper, 2005: 44; Bousfield, 2008: 95). On most occasions, however, callers will deliberately use FTAs as a 'means to some other end' (Geen, 2001: 5), such as securing some financial recompense for the problems they have experienced (Archer and Jagodzinski, 2015 ), as opposed to engaging in malice for the sake of it. In consequence, many callers are "doing" strategic verbal aggression (like our lawyers above, but for different reasons) as opposed to doing impoliteness proper. 


\section{Outline of Archer's (2011) face aggravation scale (FAS)}

In essence, my Goffman-inspired FAS is designed to account for the aforementioned strategically ambivalent FTAs (which rely on multifunctionality and indirectness) as well as intentional impoliteness acts calculated to damage face (in ways that are apparent to T).

FTA not the primary goal of S/FTA nevertheless recognised by $\mathrm{S}$ and $\mathrm{H}$.

Intentional $\left\{\begin{array}{c}\text { Intentionally ambivalent as to } \\ \text { primary goal } \\ \text { (due to [potential] multiple } \\ \text { goals/ U multi-functionality) }\end{array}\right]$

FTA as (or becoming) the primary goal of S/FTA recognised by $\mathrm{H}$.

Fig. 2. Face Aggravation Scale (Archer, 2011: 3220).

Let's explore each of these zones, in turn, commencing with the Intentional zone. From a Goffmanian perspective, intentional FTAs must be undertaken 'maliciously and spitefully' with the primary aim of causing face damage (Goffman, 1967: 14). Simply put, they are intended by $\mathrm{S}$ to be impolite moves on their part, and usually recognised as such by those being targeted. Such impolite moves can be:

- Direct/on record; as when someone utters a directive such as Get out, Marshall! You bastard (example taken from Huang, 2012: 212).

- Indirect/off record; that is, be expressed by a conversational implicature which, although theoretically cancellable, has a face-damaging 'attributable intention' that 'clearly outweighs any others' in context (Culpeper, 2005: 44). Bousfield (2008: 113-4) provides the example of concentrate on keeping your job, said by a restaurant owner to an employee, which implicitly conveys that the employee's performance to date has been so poor that he is in danger of being fired. 
In contrast to intentional FTAs (direct and off record), FTAs within the Goffmanian-inspired incidental zone are unplanned, on S's part, but S nonetheless undertakes them with the knowledge that face damage might be an anticipated by-product of their actions (Goffman, 1967: 14, my emphasis). In Archer (2008), I provide the historical example of a prisoner, Edward Coleman, who requested that the judge at his trial ask an unfriendly witness, Titus Oates, whether he was not as near to [him] as this Gentleman is because he speaks of his eyes been bad?. Notice that the question "appeared to have a "confirmation-seeking" function (that Oates was physically close to Coleman at the particular time in question)', but also suggested that 'Oates had not been honest in his previous testimony respecting his ability to clearly identify Coleman' (Archer, 2008: 197). Although implying that someone is lying is likely to be face damaging, I believe that, given the courtroom context, any consequent face damage from such an utterance is best seen as an anticipated but unplanned byproduct of Coleman's request (that Oates be asked to confirm his closeness to him) as opposed to being a deliberate attempt, on Coleman's part, to signal some personal sense of spite towards Oates. As such, this incidental facework move is different to the off-record impoliteness example above, where the face-attacking attributable intention of the restaurant owner outweighed any other(s) in context, and the employee was left in no doubt that this was the case.

The zone I created to sit between the Intentional and Incidental levels - the Strategic Ambivalence zone (see Fig. 2) - captures those FTAs where S plans to inflict face damage, but as a secondary goal only, with the result that S's face damaging intention does not clearly outweigh or take priority over any other possible/probable intention(s) S might have. Cross-examining lawyers, for example, will undertake planned actions as 'part of the strategic process of presenting evidence' (Harris, 2011: 15), fully knowing that a 'by-product' of their actions will be face damage. Usually, this means the deployment of indirect strategies to threaten face, and in ways that indicate 'some degree of contempt' (Penman, 1990: 21) or negative evaluation towards the interlocutor and, by association, the case of their opponent. However, their need to avoid legal censure usually ensures that - even though their actions are more planned than Goffmanian incidental facework seems to permit - their 
primary motive is to get to the truth (Lakoff, 1990). Or, more accurately, a truth which best represents their case. A well-known example taken from the 1991 William Kennedy Smith trial involves 'a sequence of twelve questions, all of which sought to establish the whereabouts of [a] witness's pantyhose during the night when she was allegedly raped' (Archer, 2014: 281). Eleven of these questions adhered to a Did you have ['your pantyhose'/'them'] on ['in'/'when you'] [.] pattern. However, because they each related 'to a moment in time slightly later than that in the previous question' (Conley and O'Barr, 2005: 37), the lawyer avoided transgressing US rules of evidence. Such a carefully designed set of questions undoubtedly points to planning, on the lawyer's part. Their most probable motive? To frame ${ }^{2}$ the alleged victim as a woman of loose morals: the implicit argument being that only someone with loose morals would expose their pantyhose to the opposite sex' outside of an intimate act, or 'lose track' of them 'when in mixed company' (2005: 36-7).

\section{A facework scale to capture face-enhancing and face-aggravation strategies}

My work in respect to the courtroom (Archer, 2008, 2011) and the call centre (Archer and Jagodzinski, 2015) has already shown that lines of attack characterised by strategic ambivalence are important within such conflictive contexts. For speakers can attempt to achieve goals (which are not shared by their interlocutors) whilst maintaining an element of plausible deniability (should they require a linguistic means of escape from their "skirmish"). Speakers and hearers do not only 'deliberately exploit ambivalence' with verbal aggression in mind, however. Indeed, they can also do so for 'reasons of politeness and expediency' (see, e.g., Leech, 1977; Brown and Levinson, 1978, 1987; Thomas, 1983). Leech (1977: 99) provides the example of Would you like to come in and sit down?, which could serve as 'an invitation, a request, or a directive' depending on the context, or, if it was 'in the speaker's interest' for 'the precise force...to remain unclear', 'could be deliberately

\footnotetext{
${ }^{2}$ See Locher and Watts (2008) for a description of framing.
} 
poised on the uncertain boundary between all three'. The second facework scale I have devised (see Fig. 3) has been designed to capture both face-enhancing and face aggravating strategies - be they (i) overt strategies or (ii) strategies which rely upon a level of strategic ambivalence (because of serving multiple goals for $\mathrm{S})$.

FTA as (or becoming) primary goal of $\mathrm{S}$

FTA recognised by $\mathrm{H}$

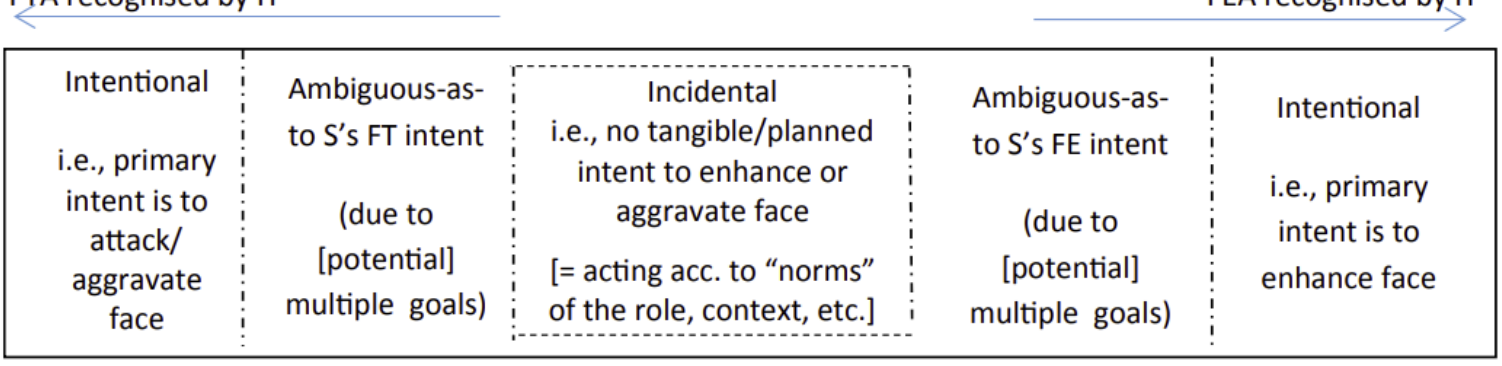

Fig. 3. Facework Scale outlining face-enhancing as well as face-aggravating levels.

As highlighted in the Introduction to this paper, the above facework scale is based on the assumption that face enhancement devices such as compliments represent the positive end of a pragmatic space relating to $S^{\prime} s$ evaluation of the addressee, and face aggravation devices such as insults or slurs, the negative end; and a related belief that such a shared evaluative space helps to explain why compliments can sometimes function as insults in context, and insults, slurs, etc., can sometimes be intended/inferred as banter (given a particular set of circumstances).

\subsection{Banter}

Let's pick up, first, on banter, by considering an example (from Culpeper, 2005: 43) where two hosts were able to explicitly 'set the record straight' in respect to the accusation that the judges on the UK talent show they hosted were 'ill-informed': 
(3): $\quad$ Extract from Pop Idol (aired in the UK 2001-2003)

Ant: $\quad$ our judges have been accused of being ill-informed, opinionated and rude.

Dec: $\quad$ we'd like to set the record straight: our judges are not ill-informed

Notice, however, that as the second host, Dec, did not explicitly 'set the record straight' with respect to all of the negative evaluations within Ant's list, it served to generate the implicature that the judges were 'opinionated and rude'. As I highlight in Archer (2011), flouting the Quantity maxim (Grice, 1975) in this (tongue-in-cheek) way constituted banter as opposed to off-record impoliteness in context. ${ }^{3}$ For, whilst Dec wanted the audience to infer some meaning beyond the literal one (such as the judges possibly being guilty of being 'opinionated and rude'), he did not want to be seen as acting out of spite or malice in doing so. On the contrary, he seems to have wanted the audience to understand that his primary facework intent was to "do" humour that did not so much make the judges the butt of the joke but, rather, allowed the judges to collude with the hosts (Ant and Dec), as well as them, in the humorous event (cf. Edelmann, 1994: 253). In which case, this particular example can be seen as sitting more within the face-enhancement zones than within the faceaggravation zones of the facework scale (see Fig. 3). Which of the FE zones, however, will depend on whether we (i) believe Dec's communicative intent is overwhelmingly one of face enhancement, or (ii) believe him to have additional communicative intents which served to supersede (i). Following Leech (1977: 99), we may also want to allow for the possibility that Dec deliberately left 'the precise force' of his quip 'unclear' so that it might sit on the fuzzy boundary between face enhancement and face threat (cf. Section 4). This possibility is allowed for, in Fig. 3, by not having an explicit divide between the ambiguous-as-to S's FE intent zone and the ambiguous-as-to S's FT intent zone (see also Section 4.5). A related phenomenon, at least in facework terms, is a modern form of ritualistic verbal duelling known as African-American sounds. African-American sounds are designed so that $\mathrm{S}$ can insult T without T feeling that his face has been seriously threatened, in reality, because each

\footnotetext{
${ }^{3} 3$ Compare Culpeper's (2005: 43) assessment of the same extract as 'sarcasm' or 'insincere off-record politeness'.
} 
knows that the insult does not really represent an 'accurate statement of reality' (Smitherman, 1977: 133-134). ${ }^{4}$ Indeed, the sounding competition has more to do with eloquence and social maintenance than dispensing face damage, according to Arnovick (1999: 24-25; cf. Leech's, 1983: 142-144 definition of banter as something that, being obviously untrue and obviously impolite, can be used for purposes of solidarity or social bonding). ${ }^{5}$ Here, we might also return to the reappropriation of nigger as represented by extract (1), where the label seems to have become a positive in-group identity marker that (depending on context) can exude proud/eloquent signals of affection and/or 'a defiant demonstration of ownership' (Galinsky et al., 2003: 234). As extract (2) reveals, such 'proprietary' undertones seem to mean, in turn, that, for members of 'a range of outgroups' (Galinsky et al., 2003: 234) at least, it can be extremely difficult to be heard to be using nigger in face-enhancing ways (cf. Section 4.7).

\subsection{Impoliteness}

The above instances of (probable) face enhancement are very different to insults or slurs which are characterised by personal spite or malice and, hence, constitute intentional impoliteness. Here, then, we are discussing a zone that also appeared in the FAS model (as revealed by Fig. 2: see also Section 3). An extreme form of (intentional) impoliteness is that of emotional venting. Consider the following historical example, cited in Archer (2011: 3225):

(4) Treason Trial of Lady Alice Lisle (1685)

LCJ. Why, thou vile Wretch ... Dost thou think because thou prevaricatest with the Court here, thou can'st do so with God above ...? How durst you offer to tell such horrid Lyes in the presence of God and of a Court of Justice? ... Thou art a strange

\footnotetext{
${ }^{4}$ Some viewers of the UK version of the Pop Idol programme may wish to argue that Dec's assessment of the judges as 'opinionated and rude' was 'an accurate statement of reality', thereby making my earlier banter interpretation somewhat problematic. I would maintain, however, that such a blanket view misrepresents the individual judges, whilst also ignoring non-verbal body language cues between the hosts and the judges (their smiles especially).

${ }^{5}$ Sounding has also been described as a mechanism through which young African-American males, in particular, learn to exercise or express "coolness" (see Morgan, 1998: 253).
} 
prevaricating, shuffling, sniveling, lying Rascal ... And why did'st thou tell so many Lyes then? Jesu God! ...

Although the judge in question - George Jeffreys - was known then, as he is now, for being 'scandalously vicious' (Woolrych, 1852: 4), his emotional outburst was not entirely unprovoked, as the witness (Dunne) had not offered any response to eleven questions posed to him by this point (in spite of being pushed for an answer). Even so, such a mixture of name-calling (vile wretch, strange, prevaricating, shuffling, snivelling, lying Rascal), accusation (you offer to tell such horrid Lyes) and profanity (Jesu God!) served to create an illocutionary booster which, in turn, served to heighten 'the negative interpersonal intent' (Holmes, 2000: 159; Bousfield, 2008: 72) - leaving those present in no doubt in respect to Jeffreys' feelings towards Dunne.

Well-known modern examples of emotional venting episodes include those involving the American actors Christian Bale and Alec Baldwin. Bale engaged in an expletive-laden rant at a crew member during the filming of a Terminator movie (an extract of which is replicated below - see (5)). Baldwin is claimed to have left his daughter, Ireland, who was 11-years-old at the time, an answerphone message in which his references to her and her mother (Kim Bassinger) had the linguistic effect of dehumanising them: he asserted that Ireland was 'a rude thoughtless little pig' who 'd[id]n't even have the brains, or the decency, as a human being', and that Kim 'was a thoughtless pain in the ass' (see Culpeper, 2011: 223 for full transcript). In his description of the use-conditions of expressive terms, Potts (2008: 13) emphasises how expressive terms will either correlate with S 'being in a heightened emotional state' or be designed 'to create that impression'. ${ }^{6}$ Thus, here - and also in respect to Croom's (2013: 183) description of the use-conditions of slurs (see Section 1) - we are reminded that some pragmatic devices are as much to do with self-presentation and impression

\footnotetext{
${ }^{6}$ See also Culpeper's (2011: 223) definition of affective impoliteness as 'the targeted display of heightened emotion, typically anger, with the implication that' $T$ 'is to blame for producing that negative emotional state'.
} 
management as they are other-presentation. This is especially obvious in respect to Bale's rant at Shane Hurlbut.

I will kick your ass. I want you off the fucking set. No, don't just be sorry. Think for one fucking second. What the fuck are you doing? Am I going to walk around and rip your fucking lights down in the middle of the scene? So why the fuck are you walking right through? You do that one more fucking time and I'm not walking on this set if you're hired (Cited in Cheung and Pittam, 2012: 262)

Swearing in such a venomous way is recognised to be an impoliteness strategy (see Culpeper's, 1996: 358 abusive or profane language sub-strategy), especially when that swearing is aimed so directly at T and overtly seems to seek disagreement, as here (Culpeper, 1996: 357). In fact, Bale's emotional venting is an example of both negative and positive impoliteness. That is to say, Bale directly imposed on Hurlbut's freedom of action, as a means of getting him off the set whilst simultaneously showing a heightened level of disapproval in respect to the Director of Photography. In so doing, Bale's tirade served to present him as someone who should not be crossed lightly (and thus served instrumental ends in this particular case). The 1649 Trial of Charles I provides us with a further example of the framing potential of facework. And it is one in which the Lord President (i.e., the judge) made use of the slur, delinquent:

The framing incident occurred at the point that Charles was being critical of the Court he faced: he had stated that he 'value[d] it not a Rush', and could not 'acknowledge a new Court that [he had] never heard of before'. Significantly, when he sought to be 'give[n] time', so that he could explain why he could not answer his charge, he was interrupted. The king appeared to take offence at this, for he told the Lord President that he 'ought not to interrupt' him. But the Lord President's response was to initially forbid Charles from 'fall[ing] into those discourses' and then inform him that he 'appear[ed] as a Delinquent', not least because he had 'not acknowledged the authority of the Court'. When Charles again refused to comply, he was removed from the Court (Archer and Culpeper, 2011: 124).

At the time, delinquent had denotative meanings which were negatively primed (that $\mathrm{X}$ had 'failed in duty or obligation' or was 'guilty of an offence' or 'misdeed') as well as a derogatory war-specific meaning, from the President's perspective: it was 'applied by the Parliamentary party to those who 
assisted Charles I ... by arms, money, or personal service, in levelling war' (OED, online), that is, their sworn enemies. It is therefore difficult to argue that this was anything other than intentional face aggravation, on the Judge's part (see Fig. 3).

\subsection{Sarcastic versus deceptive compliments}

Similar to emotional venting, sarcastic compliments are characterised by a negative evaluative intent on S's part (Eckert and McConnell-Ginet, 2003: 145). In essence, a sarcastic compliment 'does something like mime an apparent compliment in order to [blatantly] mock it. It insults by appearing to compliment but making obvious that the putative positive evaluation in this situation is judged laughable, [and] absurdly off the mark' (Eckert and McConnell-Ginet, 2003: 130). Thus, like slurs, the real objective on S's part is to lower T's social capital (Croom, 2013), and, in many cases, precipitate a level of (intentional) face damage. Eckert and McConnell-Ginet (2003: 133) provide the following example where a girl (Tricia) uses a sarcastic compliment to counter a boy's overt insult:

(6): Boy: All these girls are dogs!

Tricia: Oh, but you're a real fox.

Taken from Bousfield (2008: 119), extract (7) following, also involves sarcasm - but, in this instance, S feigns concern for T's plight. As in (6), however, its performance is 'obviously insincere', not least because of the increased loudness in delivery (signalled by capitalisation). As such, it 'remain[s a] surface realisation' only (Culpeper, 1996: 356).

(7): $\quad$ Extract from Soldiers To Be (aired in the UK from 1999 to 2001)

Context: Following his unsatisfactory showing at the morning's barrack room inspection, Private Baxter (S2) has an appointment with the Company Sergeant Major (S1). S1 is reprimanding S2 about his failure to get a haircut.

S1: $\quad$ why did you get it cut . COME ON THEN. SPEAK TO ME

S2: the queue was very long sir [and I

S1: $\quad$ [OH DEAR UNFORTUNATELY you had to queue up 
In terms of my facework scale, the example would therefore fall within the intentional face aggravation zone again - and thus be open to being understood as being intentionally impolite in context (see Fig. 3). Let's turn our attention, now, to deceptive complements. Deceptive complimenters are primarily driven by self interested motives, and are 'calculating' when it comes to achieving their goal(s). By this I mean, they will enhance T's 'good feelings about themselves not as an end...but simply a means' (Eckert and McConnell-Ginet, 2003: 130). Eckert and McConnell-Ginet provide the example of 'the waiter who routinely compliments her customers, not to make friends, but to increase her tips'. This is an interesting example not least because we might argue that, from T's perspective at least, the waiter seems to be engaging in intentional face enhancement (see Fig. 3). Given their face enhancement serves self interested motives under the veil of appearing to be other-sensitive, however, we might want to allow for the possibility that any intent we actually attribute to $S$ is more likely to slide into the FE zone relating to strategic ambivalence and, potentially, into the incidental zone (cf. Section 3), if such compliments from a waiter are so 'routine' that they constitute a norm in facework terms (Mills, 2003).

In the case of some deceptive compliments, $\mathrm{S}$ may be seeking to hide a particularly negative intent from T (cf. emotional vents and sarcastic compliments above):

[.] modern deceptive compliments [can] thus function in a similar way to Kopytko's (1995: $518,520)$ "cunning" politeness variable: designed with Shakespearean data in mind, the cunning variable signals instances when Shakespeare allowed his characters to use politeness strategically to induce other characters to satisfy their wants (cf. S using politeness purely as a means of attending to the target's positive face) (Archer, 2010: 394).

The use of strategically ambivalent facework is especially characteristic of the Shakespearean character, lago. lago was able to trick his master into believing false clues concerning his wife's supposed infidelity - and he did so by hedging his 'initial overtures in ostentatiously polite forms' (Magnussan, 2004: 178): 
I do beseech you,

Though I perchance am vicious in my guess -

As I confess it is my nature's plague

To spy into abuses, ...

... that your wisdom then,

From one that so imperfectly conceits,

Would take no notice, nor build yourself a trouble

Out of his scattering and unsure observance.

I humbly do beseech you of your pardon

... - but I am much to blame,

For too much loving you.

My Lord, I would I might entreat your honour,

To scan this thing no farther ...

Yet, if you please to hold him off a while,

You shall be that perceive him and his means.

Such 'indirect and convoluted politeness forms are suited both to the large power difference between lago and Othello' and also 'the serious face threat involved in asserting Othello's wife's infidelity', of course (Magnussan, 2004). However, lago was using this strategy of hiding behind "politeness" to deliberately exploit the ambivalence of his assertions and protestations. That is, he wanted to invite - and, arguably, intensify the negative aspect of - Othello's erroneous inferencemaking (cf. Section 4). According to Kilduff et al. (2010: 45), some subordinates use similar strategies to lago on their superiors today, especially in respect to 'strategically selecting what information they present to supervisors in order to ingratiate themselves'. This said, most appear to do so in ways that suggest some face-sensitivity to a specific other (Penman, 1990). For example, they will 'provid[e] to the supervisor affirming evidence, opinion and praise, while sheltering the supervisor from counter-evidence and criticism' (Kilduff et al., 2010: 45, my emphasis). Such other face sensitivity is not what motivated lago. Rather, lago was seeking to keep the truth from Othello such that his Master would continue to believe his self-serving misrepresentation of Desdemona: hence, Magnusson's (2004: 179) conclusion that lago's verbal skill or "linguistic capital" was centred in his ability to exploit 'characteristic rhetorical forms and logic - including not only politeness forms but also the inference-generating strategies identified by H. Paul Grice'. Croom (2013: 14-5) also draws 
on a marketing analogy, when discussing slurs. However, rather than building on Bourdieu's (1977) notion of linguistic capital - as Magnusson does - Croom opts for the notion of "social capital" thereby building on Goffman's (1967: 40) suggestion that interlocutors engage in a mutual contract of 'ritual care'. That is to say, interlocutors tend to grant one another's social identity an adequate level of respect: unless, of course, $\mathrm{S}$ wants to use a facework resource such as slurring in order to strategically 'facilitate competition, coalition breakdown', etc. Under such a notion, in which case, genuine compliments equate to $S$ first depositing into T's social capital and, then, $\mathrm{S}^{\prime} \mathrm{s}$ own metaphorical bank of social capital (if successfully received) - and, hence, sit nicely within the intentional face enhancement zone of my facework scale (see Fig. 3). Deceptive compliments, on the other hand, aim to give the appearance of depositing into T's social capital as a priority, but are primarily designed to increase S's own social capital. In which case, they seem to be doing intentional face enhancement (from T's perspective) but are actually engaging in facework which is strategically ambiguous (from S's perspective).

\section{4. (Strategic) face enhancement}

In the previous section, I highlighted how a waiter will make use of strategic face enhancement strategies with their customers as a means of increasing their tips. It is probable that most sales assistants are also engaging in strategic face enhancement, given their continuing role is almost certainly reliant on their company making a requisite number of sales. Even so, it makes sense for sales assistants to be credible (or, at the very least, appear to be credible) when engaging in such face-enhancement strategies: for likeability is shown to influence customers' loyalty to a particular product and even the personnel selling it (Cialdini, 1993). Strategic face enhancement can be difficult to do well in some circumstances, nonetheless. Consider the following extract taken from a 2014 semi-final of the British talent show, Britain's Got Talent. The show usually involves four talent

\footnotetext{
${ }^{7}$ Watts (2003) has also drawn on Bourdieu's marketing analogy, when discussing relational work (Watts' preferred term for facework).
} 
judges (Simon, David, Amanda and Elisha), who are invited to give their assessments of contestants' performances (by hosts, Ant and Dec). In this case, the judges have just listened to Keiran and Sarah sing the Freddy Mercury classic, Barcelona.

(9): $\quad$ Britain's Got Talent (semi-final show, aired 29th May 2014)

Simon: Arr, look. I think within the range of your capabilities you did really really well so [whereas before I could see you singing on a ferry now I see you on

Sarah: [thank you

Simon: an ocean liner. so you've gone up

Kieran: [Yes

Sarah: $[$ Yep

Simon: But I don't see you above that which is credible recording artist because your voices just aren't that good to sing that kind of record well. Having said that in terms of effort it was amazing

Kieran: [thank you thank you very much Simon

Sarah: [thank you that means a lot

Here, we are focussing specifically on Simon's comments to Keiran and Sarah. Notice in particular that, although Simon's first main clause constituted praise (you did really really well), and hence face enhancement, the would-be compliment was pre-qualified by a potentially face-threatening prepositional phrase (within the range of your capabilities). The implicit message, then, seemed to have been that, although Keiran and Sarah were not exceptionally talented, they did appear to maximise on the talent they had. Simon then went on to show - both with a hand gesture and through his words - how, from his perspective, they had gone up from being ferry singers to now being ocean-liner singers. In theory, this should have appealed to their positive face (i.e., their want to be approved of: Brown and Levinson, 1987), because Simon was showing approval in respect to what he had heard. The comparison itself was not without face threat, however. Firstly, because of the possible connotations attached to being referred to as ocean-liner singers. Secondly, because of Simon's next assertion that he did not see them above that, which is credible recording artist, followed by his clarification that their voices were not good enough to sing that kind of record well. 
Simon concluded his feedback with having said that in terms of effort it was amazing - and it is this inclusion, in particular, which suggests to me that Simon was continuing to make an effort to do some face enhancement throughout his exchange with Keiran and Sarah. This said, I would argue that his strategy seems to have been characterised more by incidental facework than it was intentional face enhancement (see Fig. 3). Indeed, Simon seems to have been acting squarely within his role as judge - by giving Keiran and Sarah what, for him at least, constituted a fair assessment of their abilities. If accepted, this would mean that incidental facework always has the potential to be perceived as face damaging or face threatening by others (whether that other are the targets themselves, or someone in an overhearer position, like the audience) - hence its position within my Facework Scale (i.e., straddling the FEA and FTA zones: see Fig. 3). Extracts (10a) and (10b), below, provide an account of another exchange involving Simon, taken from the same show. Allan TurnerWard had just performed his own song for the judges. It was a song which - when released 12 years previously - had reached no.1 in the pop charts of several European countries. But Only David Walliams seemed to have liked it on the night.

(10a): Britain's Got Talent (semi-final show, aired 29th May 2014)

$\begin{array}{ll}\text { Amanda: } & \text {... Simon, what do you think? } \\ \text { Simon: } & \text { well look } \\ \text { Allan: } & \text {-we know what Simon thought [laughs] }\end{array}$

As (10a) reveals, when Amanda turned to the main judge - Simon - to ask him what he thought, Allan seemed to believe that he knew what was coming, not least because Simon had pressed his red button during Allan's act, as a means of signalling that he was not very impressed. This action alone - of pressing the red button - would constitute a face threatening act, of course. Hence, Allan's comment: we know what Simon thought. Simon's response was probably unexpected for Allan, therefore, as it was deliberately face enhancing at the outset. 
(10b): Britain's Got Talent (semi-final show, aired 29th May 2014)

Simon: well I like you Alan. I think you're a fantastic plonker

General: [laughter]

Simon: but I mean that - I mean that in a positive way

Ant: $\quad$ Positive? Wow, a fantastic plonker

Simon: I find I find you fascinating

In fact, I like you directly appealed to Allan's positive face (the want to be approved of). Simon had not finished, however, for he immediately followed up this initial comment with I think you're a fantastic plonker. This phrase is somewhat of a mixed message in facework terms. In Britain, plonker has a negative semantic prosody, meaning something along the lines of idiot. Yet, in this instance, plonker is pre-modified by the evaluatively-positive adjective, fantastic. When viewed in conjunction with Simon's I like you assessment, moreover, it seemed to be intimating that he liked Allan even though (and perhaps because of the fact that) he was a plonker. The audience were possibly surprised and somewhat bemused by Simon's fantastic plonker comment, given the collective laughter. As (10b) reveals, Ant - one of the hosts of the programme - also picked up on Simon's use of the noun phrase, as well as his claim that he meant it positively, by stating, somewhat incredulously, Positive. Wow. But Simon continued regardless, emphasising how he found Allan fascinating. At which point, we could convincingly argue he was being more overtly face-enhancing once again. Given what precedes I find you fascinating, however, it is quite understandable that some people may have interpreted Simon's comment(s) as a sign of his pomposity. As such, then, when we consider Simon's exchange with Allan overall, there are enough clues here for us to recognise that this exchange is not straightforwardly face enhancing on Simon's part. In part, this is because Simon was doing something else as well as doing face enhancement: as in (9), he was turning someone down but without being overtly rude about it (which is something that Simon Cowell is very capable of doing, when he chooses). This said, the use of plonker suggests to me that this was not the prototypical kind of incidental facework we would expect a judge of a talent show to engage in (even if that judge is Simon Cowell). As such, I would suggest that this example sits best 
within the ambiguous-as-to-FE-intent zone of my facework scale (see Fig. 3: see also Section 4.5

'Back-handed compliments').

Our next example of strategic face enhancement (from Jane and Buckley, 1999) is a different type of interaction from those explored hitherto in this paper. It involves a police officer and a man who was suspected of stealing from their employer. As with (8), (9), (10a) and (10b), it contains elements of face-enhancement which are strategic in nature. However, in this case at least, it continues to have the potential to be perceived as extremely face-threatening overall by T (given S's underlying assumption, throughout, that $\mathrm{T}$ was a thief).

\section{(11): $\quad$ Police interview extract}

Andy, I know that during your two months here you have done an exceptional job. You have demonstrated your capabilities time and time again. That is why it becomes so important for us to clear this matter up. I am convinced that what you did here was out of character, and I believe it happened because of the strain all of us are under to pay our bills and take care of our families. The way our economy is going, we just can't keep up. We are falling further and further behind. The cost of everything just keeps going up, but the money we make doesn't always go up as much as it should, so we fall behind. I am convinced most of the people I talk to are good, hard-working people who have simply made a mistake. They have done something against their better judgment because they are under the strain of trying to pay everyday bills on a paycheck that is simply not adequate. I'm convinced, Andy, that if you had gotten the kind of pay you needed to keep up with things, we wouldn't be sitting here today. This wasn't an act of the criminal we read about - this was something you did because you saw no other way to make ends meet.

Note, in particular, how the officer informed the suspect that he knew that he had done an exceptional job for the business previously, and demonstrated his capabilities time and time again. The goal of this particular facework move was not to make the suspect feel approved of and valued (as in our previous cases). Rather, it was a way of mitigating blame. S's primary objective then? To encourage $\mathrm{T}$ to admit to the crime: hence, $\mathrm{S}$ also mentioning mitigating circumstances like the economy and a paycheck that was simply not adequate. I include this example, here, and examples of the courtroom (historical and modern) elsewhere, to demonstrate that my facework scale can account for the use of supposed face enhancement (as well as face-aggravating) strategies - and, 
indeed, a combination of both - within different activity types (cf. Archer, 2011): be it incidental facework, as in (8), intentionally faceaggravating facework, as in (4), or - as here - facework which is strategically ambiguous in terms of facework intention. Indeed, the strategies of offering a possible moral excuse or 'attempting to affix moral blame for the offense' on 'some particular circumstance' - both of which are used in (11) - are an important part of the Reid Technique (Inbau et al., 2013: 101,121, my italics). When part of the latter, moreover, they are often used by police officers to create in the suspect an incorrect inference that the "authorities" would be willing to be lenient (in the hope of prompting a confession: Vrij, 2008).

\subsection{Back-handed compliments}

Let's pick up on this idea that particular utterances (or utterance sequences) can be simultaneously face-enhancing and face-aggravating by focussing specifically on back-handed compliments. In her discussion of bad bosses, Graham Scott (2006: 68-9) bemoans employers who continually combine apparent 'praise with negative put-downs'. She explains, for example, how Herb would state things to David, his employee, which are somewhat reminiscent of Simon Cowell's comments to some of the Britain's Got Talent contestants:

(12): Herb's comments to David (a technician for a Telecommunications Company).

David, you may screw up around here a lot, but I just want you to know how much I appreciate that you never call in sick and are always here on time. That was a great job you did in helping that customer today. I just wish you could be on target more often.

According to Graham Scott (2006: 69), 'David found such comments confusing and demoralizing' not least because, once Herb had walked way, he was left wondering whether the comment he had made was meant to be 'a reprimand or [a] compliment'. Once again (cf. Section 4.1), this helps to explain why I have devised my facework scale such that there is no explicit divide between the ambiguous-as-to S's FT intent zone and the ambiguous-as-to S's FE intent zone (see Fig. 3). Consider the first example utterance, above, where David learns that - from Herb's perspective - he is 
someone who screw[s] up a lot but who is nonetheless conscientious in the sense of never call[ing] in sick and ... always being at work on time. Similarly, in the second example utterance, the possible face-enhancing potential of that was a great job is effectively nullified by Herb's wish that David could be on target more often. According to Devito (2012: 33), backhanded compliments such as the above will usually operate as insults 'masquerading as a compliment'. Indeed, even where they appear to be genuine attempts at (albeit qualified) face enhancement, on S's part, they will tend to be heard as 'criticism' by T nonetheless. This is likely because of the presence of the qualification (but see also Section 4.6). All of which suggests that - from T's perspective at least - back-handed compliments sit more within the ambiguous-as-to S's FT intent zone of my scale than they do the ambiguous-as-to S's FE intent zone.

\subsection{Stigmatising the other indirectly, via their use of slur terms}

Paradigmatic slurs are not likely to be (strategically) denied by a speaker, given their overt use in insulting, injuring, threatening the face of, or otherwise imposing a negative identity on $\mathrm{T}$ (Croom, 2013: 178). As I have shown, however, facework which is strategically ambivalent in some way(s) can also create problems for T - whether it is facework which is potentially face threatening (see, e.g., Sections 4.2 and 4.3), facework which is potentially face enhancing (see, e.g., Section 4.4) or facework which is somewhat of a combination (see, e.g., Section 4.5). Let's consider once again how (because of the power afforded to them through their institutional role), cross-examining lawyers are often able to use strategic ambiguity to successfully frame their interlocutors or a third party in negative ways, whilst avoiding any claims of impoliteness on their part (cf. Section 3). A particularly relevant strategy - given the focus of this volume of papers - was that used by defence attorney $F$. Lee Bailey in the 1995 O.J. Simpson trial for the murder of Nicole Brown Simpson and Ron Goldman. Bailey asked a serving police detective, Mark Fuhrman, something rather simple (and somewhat innocuous on the surface): to confirm that he had not used the ' $N$ ' word in the past ten years (which Fuhrman immediately did). Simpson's defence team then went on to produce a series of witnesses 
who were prepared to counter Fuhrman's claim. Example (13) is taken from the evidence of one such witness:

Witness direct examination (O.J. Simpson Trial, 5th September 1995)

Q Being very careful with your answer. Did he, in describing the gangs that he worked with, describe any particular race?

A Yes.

Q Did he use an epithet well-known to the world that denotes black people and begins with ' $N$ '?

A Yes

(cited in Cotterill, 2003: 145)

The defence team's deliberate disassociation from Fuhrman's use of the racial slur nigger, in (13), may remind readers of Capone's (2013) discussion respecting the pragmatics of indirect reporting and slurring. Capone emphasised that, in order to avoid signalling some complicity, reporters of a slur must not only describe the trespasser's defamatory term using 'a suitable transformation', but do so in ways that alluded 'to the slurring character of the original phrase' (2013: 181). Capone suggested further that, as 'avoidance of greater processing costs is [often also] taken as a sign of complicity', it is better for reporters to embark on a transformation which is as overt as possible in its efforts to put distance between them and 'the offensive segment of talk' (2013: 181). The lawyer's transformation of nigger to an epithet well-known to the world that denotes black people and begins with ' $N$ ' is definitely overt in its differentiation of two voices: defence lawyer (as reporter) and Fuhrman (as transgressor). An additional benefit of this particular transformational process (from the lawyer's perspective) is that it served to further emphasise the derogatory strength of nigger by a serving US police officer. It was a strategy, moreover, which proved pivotal to the defence team's case and Simpson's ultimate acquittal. For, 'by showing that Detective Mark Fuhrman was guilty of making racist remarks', they were able to imply 'that he was [equally] capable' of other incriminatory actions he had previously denied before the jury. This included 'planting evidence, corrupting samples and lying in court - [and] all because Simpson was an African- 
American' (Cotterill, 2003: 62). Yet, at least in the example above, no direct accusation of racism, on Fuhrman's part, was made by the lawyer. Notice, too, that although the above was extremely damaging to Fuhrman (and, subsequently, the prosecution's case against O.J. Simpson), Fuhrman was unable to respond personally, for he was not part of this interaction. As such, although the interaction between lawyer and witness might be judged (on the surface) to be incidental in facework terms (see Fig. 3), I would contend that its negative framing of a third party puts it within the strategically ambivalent FT zone (from both S's and the third party's perspectives).

\subsection{The facework scale and accidental face damage}

In the Introduction to this paper, I highlighted another example involving nigger: the case of Big Brother contestant Emily Parr (see extract (2)). I also stressed, in the Introduction, that it is possible for people - of all skin colours - to use such a phrase non-derogatively, given the right in-group, coupled with the right set of circumstances. Emily seems to have mistakenly assumed that her Big Brother contestants constituted such an in-group, and the discussion in the Big Brother house, an appropriate set of circumstances. Given her interactions with her friends, we might claim that Emily also assumed that they would "understand" that she was committing herself to the belief that Charlie was from a particular ethnic group, but not to the offensive content expressed or conveyed by nigger when used as a slur (cf. Bianchi, 2014: 40). As highlighted earlier, a fourth incorrect assumption, on Emily's part, was that she was engaging in private chat, when she was, in fact, engaging in a private conversation that was simultaneously being watched by 'an invisible' audience of TV viewers (Timberg and Erfer, 2002: 15), many of whom found the broadcasting of a term such as nigger on a British TV station offensive. I account for such face damage, within the facework scale, via the addition of an accidental FTA zone which sits under the FTA-related zones: 


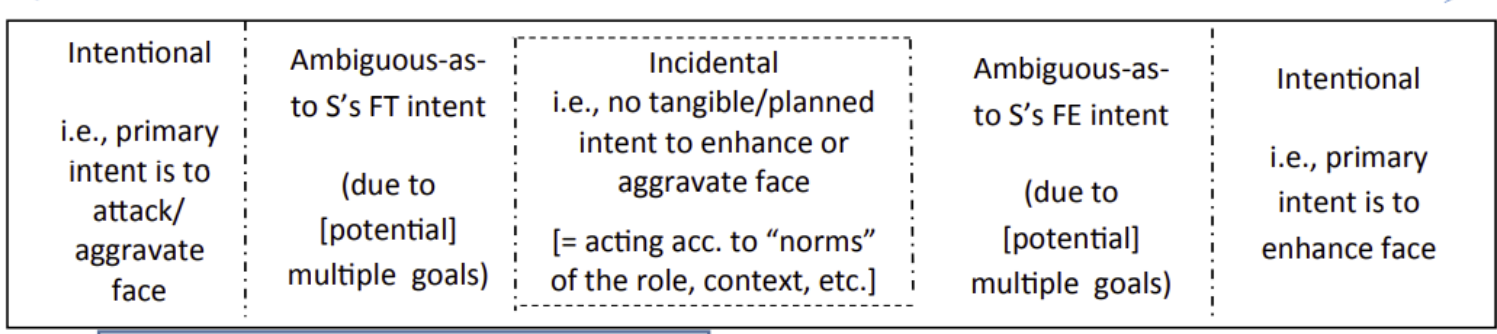

Accidental "offenses" committed by S

Plus H-constructed "offenses" (?)

Fig. 4. Facework Scale, including Accidental FTA zone.

As I explain in Archer (2011: 3227), such a zone allows 'for some activities to be perceived...differently by' T - or overhearers such as the viewing public, in the case of our Big Brother example - whilst it remaining 'possible for 'genuine' accidental face damage to be seen for what it' was, from S's perspective: namely, 'an unintended and unwitting' offense, undertaken 'innocently' (Goffman, 1967: 14; cf. Section 4.5, above). Evidence that Charlie accepted that any face damage she experienced was unintended and unwitting on Emily's part, and was something Emily 'would have attempted to avoid' had she 'foreseen its offensive consequences' for Charlie (Goffman, 1967) comes in the shape of Charlie's acceptance that Emily had meant to use the term as a means of engaging in banter with her:

$\begin{array}{ll}\text { Emily: } & \text { I was joking. } \\ \text { Charlie: } & \text { I know you were. }\end{array}$

However, whilst it seemed to do the job of mitigating any sense of (intended) offense, it is important to note that Charlie nonetheless admitted to remaining stunned by the episode. See, in particular, the comment, I'm fucking in shock. Note, too, Charlie's response to Emily's assertion that someone else in the house had already used the term:

no way near me? I'm a nigger I am one...maybe you see it in rap songs or something [.]. 
The latter, in particular, points to the argument that slurs can be re-appropriated (cf. Sections 1 and 4.1), including by 'a white kid, but only when that 'white kid' is legitimated by something other than hearing nigger used in rap songs (Bianchi, 2014: 43; Croom, 2013: 191). Indeed, it seems that, without such evidence Charlie was unable to dissociate nigger from its offensive meaning (and thus the contempt and derision this derogatory group label implies). Hence, Charlie's emotional discomfort, in spite of her acceptance that Emily had committed a "faux pas" only. In Archer (2011), I go on to suggest that the addition of an accidental zone (to interact with the FTA zones) may also prove to be useful in capturing $\mathrm{H}$-constructed impoliteness: that is, those instances where interlocutors opt to (strategically) construct an innocent offense, on S's part, as being intentionally face-attacking. Culpeper (2005) provides the example of an extended family meal at a UK fast food outlet, where A asks B to pass them a piece of garlic bread, B replies 'That'll be $50 p^{\prime}$ ', and A gives B the 50p. In some contexts, the interaction between A and B would amount to nothing more than banter. However, Culpeper suggests that, in this context, A's surrendering of the $50 \mathrm{p}$ was a deliberate attempt on A's part to reconstruct B's actions (and, by implication, B him/herself) as "mean" (in expecting 50p). In order to capture such H-constructed impoliteness, the accidental zone would need to be able to interact in some way with the incidental and/or strategically ambivalent zones whilst avoiding the Intentional zone (given this zone demands some deliberate intention on S's part'). In Archer (2011: 3227), I suggest that this might be via a dynamic politic zone which overlays the facework scale and changes its shape/position according to activity type or given community of practice involved. In a courtroom context, for example, the politic zone would likely encompass the incidental zone and much of the strategic ambivalence zone: especially given lawyers' frequent use of utterances characterised by multifunctionality and indeterminacy (in many cases, as a means of framing their interlocutors in specific ways, whilst being careful to be seen to adhere to courtroom protocol(s)) (see, e.g., Section 4.6). 


\section{Conclusion}

In this paper, I have introduced a facework scale which can account for face-enhancement acts (FEAs) and face-threatening acts (FTAs) - and, when necessary, acts that seem to have both faceenhancement and face-aggravating qualities, or, alternatively, are ambiguous as to their facework intent (because of S having multiple goals and/or expressing those goals indirectly). The FTA aspect of my scale is Goffman-inspired, in that it makes use of Goffman's (1967: 14) Intentional, Incidental and Accidental levels of face threat - where:

- The Intentional level captures FTAs which are undertaken 'maliciously and spitefully, with the intention of causing' deliberate face damage - as when $\mathrm{S}$ denigrates T using slur terms.

- The Incidental level captures those offenses which 'arise as an unplanned but sometimes anticipated by-product of action - action the offender performs in spite of its offensive consequences, although not out of spite'.

- The Accidental level captures offenses which seem 'to be unintended and unwitting' on S's part, such that 'those who perceive his act can feel that [s/]he would have attempted to avoid it had [s/]he foreseen its offensive consequences'.

Because of my interest in FEAs as well as FTAs, the Intentional level (as described above) has been adapted such that we have two intentional zones at opposite ends of the facework scale, the first of which captures acts where S's primary intent is to attack/aggravate face, and the second of which captures acts where S's primary intent is to enhance face (see Fig. 3). The Incidental level, in turn, has become an Incidental zone which captures acts for which there is no planpoliticned intent, on S's part - be it to enhance and/or to aggravate face - but a recognition (and thus anticipation) nonetheless that face enhancement and/ or face aggravation might be a possibility for $\mathrm{T}$. It is this possibility which motivates the position of the Incidental zone such that it straddles the FEA and FTA zones at the centre of the facework scale - even though I would concede that the zone will mostly 
capture facework activities that are regarded as being politic (or the norm) within a given activity type or community of practice. The Accidental level currently maintains its focus on FTAs only, and has become a zone which sits adjacent to the facework scale proper (see Fig. 4), thereby allowing S and T to have different perceptions of the same FTA (especially in respect to S's apparent intent or lack of). In addition to the above, the facework scale has an ambiguous-as-to-S's FTA intent zone and an ambiguous-as-to-S's FEA intent zone. As explained in Section 4.5, because some facework actions can be simultaneously face-enhancing and face-threatening, these zones merge into one another. That is to say, there is no explicit divide between them (see Figs. 3 and 4). Collectively, these zones provide us with a means of capturing FTA or FEA activities which are more planned than incidental facework (see above), but which are not characterised by 'spite or malice', as is the case with intentional FTAs (cf. Goffman, 1967: 14), or by a primary, over-riding intent to enhance face, as is the case with intentional FEAs. Indeed, the facework captured by these zones tends to be characterised by multifunctionality and indirectness: and, in some cases, an ambiguity which makes it difficult to determine whether the facework being undertaken is more faceenhancing than it is face-threatening (and vice versa). I have demonstrated where a number of facework strategies "sit" within the facework scale, in the paper, including banter and (failed) camaraderie (Sections 4.1 and 4.7), derogatory slurs and slur terms (Sections 4.2, 4.6 and 4.7), abusive swearing, emotional venting and insults (Section 4.2), sarcasm (Section 4.3), deceptive compliments (Section 4.3), strategic compliments (Section 4.4) and back-handed compliments (Section 4.5). I have also sought to allow for differences in perception between S and T, where/when relevant (see, in particular, Sections 4.3, 4.5 and 4.7). This includes initial differences in perceptions relating to the use of nigger (cf. Sections 1, 4.1, 4.6 and 4.7). By way of illustration, Emily Parr's attempt at camaraderie, for which see extract (2), was argued to best sit within the accidental level of the facework scale (see Fig. 4), given Charlie Uchea's admission that she was shocked by Emily's use of the term, but acceptance that Emily had not meant to offend her (see Section 4.7). In contrast, successful appropriations of nigger, as in (1), achieve their success by being blatantly face enhancing for both $\mathrm{S}$ and $\mathrm{T}$ (and their sharing a 
legitimising identity in some way: cf. Sections 1 and 4.7). As Section 4.2 revealed, prototypical slurs will always fall within the intentional face aggravation zone of the facework scale (see Fig. 3). Yet, it is possible for interlocutors to use terms such as nigger to negatively frame another without engaging in intentional impoliteness characterised by personal spite or malice (cf. Goffman, 1967). The lawyer in the O.J. Simpson trial, for example, was able to "confirm" Detective Fuhrman's status as a racist without directly interacting with him. Rather, he had a witness confirm this trespasser's use of the epithet well-known to the world that denotes black people and begins with ' $N$ '. As highlighted in 4.6, the lawyer's deliberate disassociation of 'the offensive segment of talk' in this way is reminiscent of Capone's (2013: 181) discussion respecting the pragmatics of indirect reporting and slurring. Its third-party negative framing of Fuhrman also provides us with an example of a strategically ambivalent face threat (see Fig. 3). In which case, the only facework zone that nigger and similar terms do not appear to fall within is the incidental zone (see Fig. 3). Such a finding needs to be corroborated via additional studies, as does the potential explanation for such a finding. A tentative one I will offer at this time is that the default/inherent offensive meaning(s) of such terms for many 'non-technical, non-academic, or 'lay users”' (Bousfield, 2010: 109) makes it difficult for them to become a "norm" within most communities or activity types (and hence incidental in facework terms: cf. Goffman, 1967). An exception to this could be in appropriation contexts 'where civil rights groups reclaim the use of the slur as a tool of deliberate political and social fight' (Bianchi, 2014: 37), but only where the appropriated slur is used so much that it becomes a norm for this particular community (or communities). I do not believe that 'friendship contexts' (Bianchi, 2014: 37) offer us a second possible explanation, because of their overt relational goal(s). Bianchi quotes Goffman's (1967: 86) argument, for example, that 'individuals who are on familiar terms with one another' can exchange jokes and mock insults 'as a means of poking fun at' one another. Notice, however, that this means they are intentionally engaging in face enhancement as opposed to incidental or intentional face threat (cf. Section 3): although there may be an argument for allowing some strategies to sit on the fuzzy boundary between face enhancement and face threat (cf. Section 
4.1). The use of appropriated slurs by 'artists (writers, poets, comedians, song lyricists)', etc., constitutes 'a way of subverting entrenched socio-cultural norms' (Bianchi, 2014: 37) and, as such, the whole point here tends to be to engage in relational work which shocks/offends (cf. Section 4.2) as opposed to engaging in incidental facework. The fact that I draw from Goffman's (1967) Intentional level in particular, and, in so doing, seek to 'attribut[e] purposiveness to participant behaviours' (Grimshaw, 1990: 281) means that my facework scale is reliant on the notion of intention(ality). For some researchers, this will always be problematic: especially given the (at times heated) debates within the facework literature concerning intentionality and its relationship with im/politeness and rudeness in particular (see, e.g., Culpeper, 2008; Terkourafi, 2008). My development of a facework scale which relies on intention should not be taken to mean that I believe we can get inside speaker's heads. On the contrary, I am happy to concede that 'what is in people's heads is accessible neither to analysts nor to interlocutors (nor even, ultimately, fully accessible to those whose behaviour is under investigation)' (Grimshaw, 1990: 281). This said, I would advocate - and seek to demonstrate in this paper - that we, as researchers, can reconstruct the 'plausible' intentions of speakers (i.e., make inferences and attributions which are 'for-the most practical purposes...no less plausible than those of actual participants'), given adequate evidence (Grimshaw, 1990: 281). Via the inclusion of zones which allow for ambiguity (be it strategic ambiguity on S's part, or an inherent ambiguity occasioned by the language itself), my facework scale also seeks to allow for the fact that message interpretation can nonetheless be - and often is an extremely 'dirty business' (Hewes et al., 1985: 299) for both participants and researchers alike. Indeed, our discourses will be made up of messages which are both 'inherently ambiguous' and also 'intentionally misleading' on occasion (Penman, 1990: 21). As I have shown, this might be because such messages, and the facework strategies underpinning them, were 'serv[ing] more than one goal at the same time', because the 'intent [was] expressed ... indirectly' or even because the (intended) effect was designed to be 'cumulative or even indeterminate' (Penman, 1990: 22). When done well, a strategy based on multifunctionality and indirectness can provide $S$ with an element of plausible 
deniability, as is the case with deceptive compliments and some (strategic) facework activities that appear to combine FEAs with FTAs (cf., e.g., Sections 4.3 and 4.4). But this is not always the case, as our brief discussion of back-handed compliments revealed (see Section 4.5). It should be remembered, too, that context is crucial to understanding facework strategies, for both the participants concerned and also researchers. As highlighted above, in the case of nigger for example, lawyers can use strategies to negatively frame their interlocutors without falling into impoliteness assuming they stay within courtroom protocol(s) (see also Sections 3 and 4.6). However, the same strategy - undertaken by the same person - would very likely constitute impoliteness in activity types which are, by nature, less conflictive than courtroom cross-examination. As also highlighted above, a term such as nigger can be used to denigrate in one context-of-use, but build rapport in another - assuming $\mathrm{S}$ and $\mathrm{T}$ share the same in-group, in the latter case (Section 1 ), and both believe the term is being used to communicate 'positive, non-pejorative content or meaning' (Croom, 2014: 235).

\section{Acknowledgements}

I am indebted to Adam Croom, as guest editor, as well as to the editor of Language Sciences and two anonymous reviewers for their excellent comments in respect to an earlier version of this paper. All remaining infelicities are mine.

\section{References}

\footnotetext{
Archer, D., 2014. Exploring pragmatic phenomena in English historical texts using USAS: the possibilities and the problems. In: Taavitsainen, I., Jucker, A., Tuominen, J. (Eds.), Diachronic Corpus Pragmatics. John Benjamins, pp. 277-302.

Archer, D., 2011. Cross-examining lawyers, facework and the adversarial courtroom. J. Pragmat. 43 (13), 3216-3230.

Archer, D., 2010. The history of speech acts. In: Jucker, A.H., Taavitsainen, I. (Eds.), Handbook of Historical Pragmatics. John Benjamins, Amsterdam and Philadelphia, pp. 379-418.

Archer, D., 2008. Verbal aggression and impoliteness: related or synonymous? In: Locher, M., Bousfield, D. (Eds.), Impoliteness in Language. Mouton der Gruyter, Berlin/New York, pp. 181-207.

Archer, D., Culpeper, J., 2011. Identifying key sociophilological usage in plays and trial proceedings (1640-1760): an empirical approach via corpus annotation. In: Culpeper, J. (Ed.), Historical Sociopragmatics. John Benjamins, Amsterdam/Philadelphia, pp. 109-132.

Archer, D., Jagodziński, P., 2015. Call centre interaction: a case of sanctioned face attack? J. Pragmat. 76, 46-66.

Arnovick, L.K., 1999. Diachronic Pragmatics. Seven Case Studies in English Illocutionary Development. In: Pragmatics \& Beyond Series, 68. John Benjamins, Amsterdam/Philadelphia.

Bianchi, C., 2014. Slurs and appropriation: an echoic account. J. Pragmat. 66, 35-44.

Bourdieu, P., 1977. The economics of linguistic exchanges (Richard Nice, Trans.). Soc. Sci. Inf. 16, 645-668.

Bousfield, D., 2010. Issues in impoliteness research. In: Locher, M., Graham, S.L. (Eds.), Interpersonal Pragmatics. Mouton de Gruyter, Berlin, pp. 101-134.
} 
Bousfield, D_ 2008, Impoliteness in Interaction. John Benjamins, Amsterdam/Philadelphia.

Brown. P. Levinson, S.C. 1987. Politeness: Some Universals in Language Usage. Cambridge University Press, Cambridge.

Brown, P. Levinson, S.C. 1978. Universals in language usage: politeness phenomena. In: Goody, E.N. (Ed.), Questions and Politeness. Cambridge University Press, Cambridge, pp. 56-311,

Capone, A. 2013. The pragmatics of indirect reports and slurring. In: Capone, A. Lo Piparo, F_ Carapezza. M. (Eds.), Perspectives on Linguistic Pragmatica, Springer, Dordrecht, pp. 153-183.

Cheung, H. Pittam. N. 2012 Christian Bale: the Inside Story of the Darkest Batman. BenBella Books Inc, Dallas

Cialdini, R.B. 1993. Influence: the Psychology of Persuasion. HarperCollins, New York

Conley. JM. O'Barr, W.M. 2005. Just Words: Law, Language, and Power, second ed. The University of Chicago Press, Chicago/London.

Cotterill. 1. 2003. Language and Power in Court: a Linguistic Analysis of the 0.J. Simpson Trial. Palgrave Macmillan, Basingstoke/New York.

Croom, A.M. 2014. The semantics of slurs: a refutation of pure expressivism. Lang. Sci. 41, 227-242.

Croom. AM, 2013. How to do things with slurs: studies in the way of derogatory words. Lang Commun. 33, 177-204.

Croom, AM. 2011. Slurs. Lang. Sci. 33, 343-358,

Culpeper, J. 2011. Impoliteness: Using Language to Cause Offence. Cambridge University Press, Cambridge.

Culpeper, J. 2008, Reflections on impoliteness, relational work and power. In: Bousfield, D., Locher, M.A. (Eds.), Impoliteness in Language: Studies on Its Inter-play with Power in Theory and Practice. Mouton de Gruyter, Berlin, pp. 17-44.

Culpeper, J. 2005. Impoliteness and entertainment in the television quiz show: The Weakest Link. J. Politeness Res. 1, 35-72.

Culpeper, L 1998. (Im) politeness in dramatic dialogue. In: Culpeper. L. Short, M. Verdonk. P. (Eds.), Exploring the Language of Drama: From Text to Context. Routledge, London, pp. 83-95.

Culpeper, J. 1996. Towards an anatomy of impoliteness. J. Pragmat. 25, 349-367.

Devito, JA., 2012. 50 Communication Strategies, iUniverse, Bloomington, IN.

Drew, P, 1987. Po-face receipt of teases. Linguistics 25, 219-253.

Eckert, P. Mcconnell-Ginet, S. 2003. Language and Cender. Cambridge University Press, Cambridge.

Edelmann, R. 1994. Embarrassment and blushing: factors influencing face-saving strategies. In: Ting-Toomey. S. (Ed.), The Challenge of Face: Cross-cultural and Interpersonal Issues, State University of New York Press, Albany, pp. 231-268.

Galinsky, A.D., Hugenberg, K. Groom, C, Bodenhausen, G. 2003. The reappropriation of stigmatizing labels: implications for social identity. In: Polzer, f. (Ed.), Identity Issues in Groups. Emerald Group Publishing Limited, Bingley. pp. 221-256.

Geen, RG. 2001. Human Aggression. Open University Press, Buckingham.

Coffman, E. 1967. Interaction Ritual: Essays in Face-to-face Behavior. Aldine Publishing Chicago.

Graham Scott, G., 2006. A Survival Guide for Working with Bad Bosses: Dealing with Bullies, Idiot, Back-stabbers, and Other Managers from Hell. AMAcom, Broadway, New York.

Grice, H.P. 1975. Logic and conversation. In: Cole, P. Morgan, M. (Eds.L. Syntax and Semantics 3: Speech Acts. Academic Press, New York, pp. 41-58.

Grimshaw, A. . 1990. Research on conflict talk antecedents, resources, findings, directions, In: Grimshaw, A.D. (Ed), Conflict Talk Sociolinguistic ID vestigations of Arguments in Conversations. Cambridge University Press, Cambridge, pp. 281-324.

Harris, S, 2011. The limits of politeness revisited: courtroom discourse as a case in point. In: Linguistic Politeness Research Group (Ed.), Discursive Approaches to Politeness. Mouton de Gruyter, Berlin, pp. 85-108.

Hewes, D, Graham, M. Doelger, L. Pavitt, C, 1985. "Second guessing"': message interpretation in social networks. Hum. Commun. Res. 5, 355-375

Holmes, 1. 2000. Politeness, power and provocation: how humour functions in the workplace. Discourse Stud. 2 (2). 159-185.

Huang Y. 2012. The Oxford Dictionary of Pragmatics. Oxford University Press, Oxford.

Inbau, F. Reid. J.E. Buckley. I. . Jayne, B.C. 2013. Essentials of the Reid Technique. Jones \& Bartlett Publishers, Burlington, MA.

Jagodziński, P, 2013. Impoliteness Strategies in a British Airline Call Centre; a Pragmatic Analysis of Customer Service Interactions (Unpublished Ph.D. dissertation). Adam Mickiewicz University, Poznań.

Jucker, A.H. Taavitsaineñ, 1., 2000. Diachronic speech act analysis: insults from flyting to flaming. f. Hist. Pragmat. 1.1, 67-95.

Kilduff, M. Chiaburu, D. . Menges, H. 2010. Strategic use of emotional intelligence in organizational settings: exploring the dark side. Res. Organ. Behav, 30 , 129-152.

Kopytko, R., 1995. Linguistic politeness strategies in Shakespeare's plays. In: Jucker, A.H. (Ed.). Historical Pragmatics. Pragmatic Developments in the History of Engtish. John Benjamins, Amsterdam/Philadelphia, pp. 515-540.

Lakotf, R., 1990. Talling Power: the Politics of Language in our Lives. Basic Books, New York.

Leech, G., 1983. Principles of Pragmatics. Longman, London.

Leech. G. 1977. Language and Tact. LAUT Series A, Paper 46. University of Triet.

Locher, M.A., Watts, R.. 2008. Relational work and impoliteness: negotiating norms of linguistic behaviour. In: Bousfield, D. Locher, MA. (Eds.), Impo liteness in Language: Studies on its Interplay with Power in Theory and Practice. Mouton de Cruzter, Berlin, pp. 77-99.

Magnussan, L. 2004. Shakespeare and Social Dialogue: Dramatic Language and Elizabeth Letters. Cambridge University Press, Cambridge.

Mills, S. 2003. Gender and Politeness. Cambridge University Press, Cambridge.

Morgan, M. 1998. More than a mood or an attitude: discourse and verbal genres in African-Amenican culture. In: Salikoko, S., Mufwene, J.R., Rickford, G.B., Baugh, J. (Eds.) African-American English: Structure, History and Use. Routledge, London, pp. 251-281.

Penman, R. 1990. Facework and politeness: multiple goals in courtroom discourse. In: Tracy. K., Coupland, N. (Eds.), Multiple Coals in Discourse. Multilingual Matters Ltd. Clevedon, pp. 15-38.

Potts, C. 2008. The pragmatics of conventional implication and expressive content. In: Maienborn, C. Portner, P. (Eds), Semantics: An Intemationa Handbook of Natural Language Meaning Mouton de Gruyter, Berlin (Chapter 94).

Smitherman, G. 2006. Word from the Mother: Language and African Americans. Routledge, New York and London,

Smitherman, G., 1977. Talkin and Testifyin: the Language of Black America. Houghton Mimlin, Boston.

Taavitsainen, L. Jucker, A.H. 2008. "Methinks you seem more beautiful than ever": compliments and gender in the history of English. In: Jucker, A.H. Taavitsainen, L. (Eds.), Speech Acts in the History of English. John Benjamins, Amsterdam/Philadelphia, pp. 195-228.

Terkourafi, M. 2008. Toward a unified theory of politeness, impoliteness, and rudeness. In: Bousfield, D. Locher, M.A. (Eds.), Impoliteness in Language: Studies on its Interplay with Power in Theory and Practice. Mouton de Gruyter. Berlin, pp. 45-74.

Thomas, J 1983. Cross-cultural pragmatic Gailure. Appl. Linguist. 4. 91-112.

Timberg. B.M. Erfer, B., 2002. Television Talk: a History of the TV Talk Show. University of Texas Press, Austin. TX.

Vrij. A. 2008. Detecting Lies and Deceit: Pitfalls and Opportunities. John Wiley \& Sons,

Watts, R.J., 2003. Politeness, Cambridge University Press, Cambridge.

Woolrych, H.W., 1852. The Life of Judge Jeffreys. Lindsay and Blakiston, Philadelphia. 